\title{
ЕТНОКУЛЬТУРНЕ ЛЕКСИКО-СЕМАНТИЧНЕ ПОЛЕ «РІДИНИ», РЕПРЕЗЕНТОВАНЕ В УКРАЇНСЬКІЙ МОВІ
}

\begin{abstract}
Шевченко I. Г. Етнокультурне лексико-семантичне поле «РІДИНИ», репрезентоване в українській мові.

Польовий спосіб дослідження мовних одиниць на етнокультурному тлі дозволяє дослідити мовну систему в іiі цілісності та встановити зв'язки між лексемами, що іiі формують. Стаття розглядає структуру лексикосемантичного поля «РІДИНИ» з позицій етнокультури українського народу. Здійснено класифікацію лексем на мікрополя й концептуальні зони 3 визначенням ядерних сем і складових елементів поля.

Ключові слова: лексико-семантичне поле, мікрополе, концептуальна зона, ядро, ближня периферія, дальня периферія.
\end{abstract}

Шевченко И. Г. Этнокультурное лексико-семантическое поле «ЖИДКОСТИ», репрезентированное в украинском языке.

Полевой способ изучения языковых единиц в этнокультурном плане позволяет исследовать языковую систему в ее целостности и установить связи между лексемами, формирующими ее. В статье рассматривается структура лексико-семантического поля «ЖИДКОСТИ» с позиций этнокультуры украинского народа. Лексемы классифицированы по микрополям и концептуальным зонам, установлены ядерные семы и составные элементы поля.

Ключевые слова: лексико-семантическое поле, микрополе, концептуальная зона, ядро, близкая периферия, дальняя периферия.

Shevchenko I. G. Ethnic-cultural lexical and semantic field of «LIQUID» which is presented in Ukrainian.

A field method research linguistic unit on the ethnoculchure background, to permit investigate linguistic system in her intergrity and establishment contact between vocabulary, what her to form. Article to scrutinize lexuco-sementic field «Liquid» with position ethnoculchure Ukrainian people.

Key words: lexuco-sementic field, micro field, conception zone, kernel near outlying area, zemote outlying area.

Метод польового вивчення та опису мови в контексті етнокультури створює передумови для цілісного дослідження мови як виразника i зберігача етнокультурних цінностей в їхніх загальних і специфічних рисах. Модель поля як єдності предметного i духовного світів становить теоретичну основу для опису етнолінгвокультурологічного поля, в якому співвідносяться і фокусуються елементи мови й етнокультури. Цей метод дає можливість продуктивно синтезувати знання про культуру етноспільноти, виражені в мові, бачити їхній глибокий зміст [4, с. 7-8]. Дослідження концептів як мовних явищ на основі польвої моделі 3 урахуванням специфіки національно-культурної картини світу є достатньо сформованим напрямом у сучасній лінгвістиці. Вивчення умов організації окремих слів у семантичні поля започатковано Г. Іпсеном і Й. Тріром, згодом це питання досліджують Г. Щур, 3. Попова, Й. Стернін, Ю. Караулов, І. Кобозева, О. Бондарко та ін. Роботи, де розглядаються різні типи полів, зокрема й ЛСП (О. Гулига та І. Шендельс, Г. Уфімцева, Г. Щур ) посідають провідне місце у традиційній семантиці.

Метою статті є встановлення структури ЛСП «РІДИНИ» 3 позицій етнокультури українського народу, що дозволить продовжити дослідження цього важливого для лінгвістики питання i визначити нові пласти 
лексичної семантики, зокрема ऑї одиниць, наділених сакральним значенням. Досягнення мети передбачає виконання наступних завдань: встановити ядро досліджуваного ЛСП та визначити й описати склад мікрополів, що до нього належать. Важливість використання польової організації лексики, яка характеризує концепт рідини, аргументується тим, що у процесі формування ЛСП відбувається важливий прийом виявлення смислових складників концепту - тих мисленнєвих сутностей, 3 яких складається концептосфера, чи картина світу, народу.

Виділяючи мікрополя досліджуваного ЛСП, застосовуємо семантикологічний критерій, в основі якого лежить запропонований Ш. Баллі принцип ідентифікації [3, с.128-168]. Як відзначає С. Долгих, суть цього принципу зводиться до відшукування слова-ідентифікатора, яке виражає поняття, ідею в найбільш загальній і нейтральній формі. Воно служить ніби вимірювальним приладом для інших членів поля [Цит. за 7, с. 93]. Використовуючи цей критерій розмежування мікрополів ЛСП, йтимемо від загального до часткового, від родових понять до видових.

Периферійний простір концепту рідини розкладається на периферію ближню і дальню, що, у свою чергу, складаються, 3 кількох мікрополів. Ближня периферія ділиться на чотири сектори, утворюючи такі мікрополя: 1) «вода», 2) «напої», 3) «продукти жситтєдіяльності», 4) «інші рідини». У зоні дальньої периферії виділяємо три мікрополя: 1) «водні об’єкти» (зазначимо, що це мікрополе перебуває на межі ближньої і дальньої периферії, оскільки в основі його назви лежить лексема вода, а одноіменне мікрополе очолює ближню периферію ЛСП «РІДИНИ». Це свідчить про умовність поділу лексем на мікрополя, про розмитий характер поля), 2) «рідкі страви», 3) «явища природи». У ролі ядерної семи в мікрополі «вода» виступає номен вода. Під цим началом об'єднуються лексеми, що позначають предикативні та інші назви води, що вказують на сакральну роль цієї рідини в житті української етноспільноти: благовіщенська вода, вода «Слена», дощчова вода, зоряна вода, купальська вода, наговірна вода, непочата вода, йорданська вода, правдива = богатирська вода, молодильна вода, свята вода, жива (живильна, живуща вода), мертва вода, цілюща (зцілющуа) вода, безсила вода, теплі води, свячена вода, глибока вода, каламутна вода, непогожа (несвіжа) вода, непочата вода, юрська вода; баран, бийстрик, брусини, бруя, бура, вар, вернивода, доплив, дунай, дьоготь, єлиничя, заворот, затон, зливки, розливки, капля, кипень, коловерть, комперянка, криниця, купіль, миління, митель, нетеча, нурт, облить, окріп, перетік, підмитва, плив, полій, протока, сага, саджавка, сировиця, солянка, тиховід, топіль, шум, щзава та ін.

Щоб сформувати цілісну картину мікрополя «вода», зараховуємо до його складу паремії, народнопісенні символи та назви обрядів, що включають аналізовану лексичну одиницю: багато (чимало) води утекло, піти (збігти) за водою, як вода змила (вмила), пустився на бистру воду, $i$ 
за холодну воду не візьметься, нема й промитої води (кому), воду варити, жила мінеральна, жила води підземна, кидати воду, одним лицем вода, крутиться як муха в окропі, без неї вода ніде не освятиться, нема промитої води кому, спустити воду, воду пити (брати), по воду ходити, напитися води, воду розливати, проливати воду, обливання водою, водосвяття [Знаки; Словарь].

У ЛСП «РІДИНИ» широко представлена група слів, що входять до мікрополя «напої», яке умовно поділяємо на дві концептуальні зони алкогольні й безалкогольні напої. Зону алкогольні напої, у свою чергу, членуємо ще на три групи: 1) 3 ядерною семою «горілка»: горілка, баламутка, березівка, варенуха, живиця, запікана, запридух, зелене вино, кириня, мед-горілка, медівка, мокруха, мочена, оковита, паленка, первак, перцівка, підпінок, пінна, полинівка, пориійка, родиво, сабашівка, сивуха, сливовичя, спотикач, сирвасер, икилдуха, иумівка, чімируха; 2) з ядерною схемою «наливка»: агрусівка, афиняк, вишнівка, інбирівка, калганка (-івка), калинівка, слив'янка, тернівка; 3) назви інших алкогольних напоїв: баша, брага, вино, ведмедик, кантабас, канун, пиво, тертуха. У ролі ядерної семи в цьому мікрополі виступає лексема напій = пивота. Поряд із нею визначимо лексему пійло, яка в одному зі своїх значень (поганий напій взагалі) входить до ядра мікрополя нanö̈.

Концептуальної зона безалкогольні напої представлена широким колом назв: ар'ян, білашка, вимочки, дійво, засилка, кава, квас, квас шевський, квасило, кулястра, малинник, молоко і такі його різновиди, що мають етнокультурний характер: молодильне молоко, кобиляче молоко, бугаєве молоко, звіряче молоко; муселець, подій, покорм, ряжанка, колотуха, сметана, гуслянка, пряжанка, сироватка, сирівецьь, сиродій, cuma = ситиия, стоянка, узвар, чай. До мікрополя» «напоӥ» також відносимо лексему дання, вивівши їі окремо поза концептуальні зони цього мікрополя.

Окремо виділяємо назви рідин, що через свій власне символьний характер часто наповнені культурологічним змістом. Їх умовно об'єднаємо в мікрополе «продукти життєдіяльності»: жовч (у спол. аж у нім жовч кипить, виливати жовч), кров (мазка, пасока, паюха, руда), (кровна рідня, кровна помста, кровний союз, кровна жертва, голос крові, «Кров $і$ кров'ю не змиєш», «Людська крівия не водиця, розливати не годиться», «Кров - не вода, а серце - не камінь», серце кров'ю закипає, залитися кров'ю, кидати кров), молозиво (у спол. іти до кого на молозиво), nіт («робити до сьомого поту», «працювати до кривавого поту», піт проймає, циганський піт), ропа, сеча, слина («Аж йому слинка в рот набігає», "Аж слинку ковтає»), сльози ("Поплач, щзоб легше стало», чистий, як сльоза, народні епітети: гарячі, пекучі, рясні, дрібні, гіркі, криваві, кревні, горючі, палкі, палючі; предметні характеристики: 
умиватися, обливатися, заливатися, захлинатися, розливатися сльозами; проливати сльозами, розпустити сльози), сукровиця.

Останній сектор зони ближньої периферії формує мікрополе «інші рідини», до складу якого входять такі лексеми: джурджя, дзер, жентиия, дьоготь, луг, маляса, масло, миро (одним миром мазані), нафта, олива (оливна лампада), олія (олію бити, олію вибити, давити олію), патока, перекалка, помиї (в помиях утопити), рідота, ропа (як ропа).

До дальньої периферії досліджуваного ЛСП входять три мікрополя: «водні об'єкти», що залежно від значення і графічного оформлення мовних одиниць ділимо на дві концептуальні зони й умовно їх визначаємо як назви власні $i$ загальні; «рідкі страви» (страви для тварини, страви, щзо вживає людина); «явища природи» (з концептуальними зонами дощ, роса).

До власних назв водних об'єктів входять такі лексеми: Бакал, Білозерка (Білозірка), Борисф(m)ен, Дніпро («Роби, як Дніпер робить», Дніпро-батько), епітети Дніпра: Славута = Славут = Словутиия; Дністер Дністро), Дон - Дін, Донещь, Дунай, Забудь-річка (Вогненна річка, Лета, Лато, Літо), Йордан[b] = Йордан - Йорданка -Ордан[b], Молочна річка (молочні ріки, кисельні береги), Чорне море (Козацьке море). Серед загальних назв водних об’єктів виділяємо такі: болото (багно, багнище, багнисько, багнюка), («У тихому болоті чорти водяться, «Де болото, там i чорт сидить»), багрина, драговина, жабокряківка (жабар), бабині животи, вериина, виполоч, вир (омут, водоворот, коловорот, крутень, чортове коло, чорторий), гало, джерело, єзвіро, копанка, мокрина, мокряк, море (житейське море, той бік моря), мутник, озеро, озерявина, океан (окіян, море-окіян), плесо, річка-живоробка, молочна річка, рудка, ручай, самоте(о)ка, став, ставище, стрижень, струмок.

Мікрополе «рідкі страви» умовно поділене на дві концептуальні зони. Страви, які вживає тварина: бевка, бовтанка, заминка, запарка. Страви, щзо споживає людина: афинянка, бануш, борщ (борщ - хазяїн, борщ - найстарша страва, голий борщ), бузинник, джигун, жсур, забіл, зарядка, капусняк, кванька ("Добра кванька, та нема лоньки, хіба буду пальком»), кваша (показати, почому лікоть кваші), кисіль (жалю по киселю, сьома вода на киселі), коливо, крупник, куліш («Хоч куліш, та з перием»), кутя (Багата (Різдвяна) кутя, Голодна кутя), лизанка, молочина, паруха, підчас, повидлянка, просілне, путря, саламаха (соломаха, саламата), сапетон, слив'янка (сливовичя), софорок (супорка), суп, тетеря, уха (юха) (собача юха, набратися чиєї юхи), чєра, шчерба, юшка («Дешева рибка - погана юшка», юшки московської ухватити).

Через тісний зв'язок 3 основним мікрополем ЛСП «РІДИНИ», «водою», віднесеність мікрополя «явища природи» до дальньої периферії $\epsilon$ умовною, тільки через те що тут представлені назви не власне рідин, а уже похідні від однієї з них. Формуючи ЛСП з ядром вода, мікрополе «явища природи» займали б одне з центральних місць у зоні ближньої периферії. У 
мікрополі «явища природи» чітко виділяються дві концептуальні зони - зі стрижневими компонентами дощ i роса, а також окремі автономні лексеми. До концептуальної зони дощ належать такі лексеми та вирази: дощ і його епітети: курячий, свинячий, грибний, заячий, циганський, дівочий, теплий, рудавина, сліпий дощ, дрібний дощик; інші назви на позначення дощу: залива = злива, ляпавиця, мжичка, мжа, мжичя, моква, мокротеча, мочва, мряка, плова, плюта, пролій, сплав, сплющяа, улива. Концептуальна зона роса: роса (росиия, росонька, ранкова роса, юр'євська роса, купальська роса, Божа роса, «з роси вам», перегнати на росу кого. До складу мікрополя «явища природи» входять ще й такі лексеми: павідь (повідb, повінь), туман (безпросвітний, блаженний, важкий, в'язкий, каламутний, легкий, мрійний, невиразний, п'янкий, солодкий, тоскний, тяжкий, хмільний), тумана перти, туман навести на кого.

До складу ЛСП «РІДИНИ» входить ряд лексем, що через неоднорідний характер своїх лексичних значень можуть входити до різних мікрополів або ж до інших ЛСП. Назвемо для прикладу лише окремі з них. Лексема дьоготь у своєму основному значенні (темна густа в'язка смолиста рідина з різким запахом [Стсум; с. 224] входить до ЛСП «РІДИНИ», однак належить до мікрополя «інші рідини». У другому ж значенні (образ весняних вод, розталих від променів ясного сонця i весняного дощу [Войтович] це слово входить до мікрополя «вода». Подібна ситуація 3 лексемою Коломия, що залежно від орфографічного оформлення в сучасній українській літературній мові набуває різних лексичних значень і здатності належати до різних ЛСП. Як загальна назва слово Коломия використовується на позначення глибокої вимоїни 3 водою [Словарь], тому належить до мікрополя «вода». Власна назва цієї лексеми $\epsilon$ географічною назвою, що входить до іншого ЛСП. Здатність слів формувати різні ЛСП і мікрополя є доказом існування єдиної цілісної лексичної системи і свідчить про зв'язок лексем та можливість переходу від одного поля до іншого, не порушуючи цілісності системи.

Питання лексико-семантичного поля в мовознавчій літературі не нове, однак його актуальність не згасає, оскільки дозволяє відкривати все нові сторони лексичної системи і встановлювати нові зв'язки між членами системи. Лексико-семантичне поле «РІДИНИ» служить яскравим прикладом сказаному, оскільки $є$ самостійною наповненою системою лексичних одиниць, що перебуває в тісних зв'язках з багатьма полями системи сучасної української літературної мови.

Література

1. Антомонов А. Ю. Исследование структурной организации лексико-семантического поля / А. Ю Антомонов : дис.... канд. филол. наук : 10.02.19. / ИС 71987. - 191 с.

2. Апресян Ю. Д. Интегральное описание языка и системная лексикография : избр. труды Ю. Д. Апресян. - М. : Шк. языки русской культуры, 1995. - Язык. Семантика (Культура). - Т. 2. - 768 с.

3. Балли Ш. Французская стилистика / Ш. Балли. - М. : Иностр. литературара, 1961. - 304 с.

4. Виноградов В. В. Основные типы лексических значений слов / В. В. Виноградов // Вопр. языкознания. - 1953. - №5. - С. 3-29. 
5. Воробьев В. В. Лингвокультурология : [монография] / В. В. Воробьев. - М. : РУДН, 2008. - 136 с.

6. Денисова С. П. Типологія категорій лексичної семантики / С. П. Денисова. - К. : Вид-во Київського держ. лінгв. ун-ту, 1996. - 294 с.

7. Дятчук В. В. Семантична структура і функціонування лексики української літературної мови / В. В. Дятчук, Л. О. Пустовіт. - К. : Наук. думка, 1983. - 155 с.

8. Кронгауз М. А. Семантика : учебник для вузов / М. А. Кронгауз. - М. : Рос. гуманит. ун-т, 2001. - 399 с. Джерела та їх умовні скорочення

Войтович - Войтович В. Українська міфологія / В. Войтович. - К. : Либідь, 2002. - 662 с.

Дмитренко - Дмитренко М. Народні повір'я / М. Дмитренко. - К. : Ред. часопису «Народознавство», 1997. - 68 с.

Знаки - Жайворонок В. В. Знаки української етнокультури : Словник-довідник / В. В. Жайворонок. - К. : Довіра, 2006. - 703 с.

Словарь - Словарь української мови : у 4-х т. / За ред. Б. Грінченка. - К., 1996 - 1997.

Стсум - Сучасний тлумачний словник української мови / За заг. ред. В. В. Дубічинського. - Х. : ВД «ШКОЛА», 2006. - 832 c. 